Post-print of For. Ecol. Manage. 386:13-21.

DOI: $10.1016 /$ j.foreco.2016.11.019

\title{
Survival and growth as measures of shade tolerance of planted western redcedar, western hemlock and amabilis fir seedlings in hemlock-fir forests of northern Vancouver Island.
}

Adrian Weber ${ }^{1}$, Sara Leckie ${ }^{2}$, J. P. (Hamish) Kimmins ${ }^{3}$, Benjamin Gilbert ${ }^{4}$, Juan A. Blanco ${ }^{5}$, Yueh-Hsin $\mathrm{Lo}^{6, *}$

* Corresponding author: Yueh-Hsin Lo

Dep. Ciencias del Medio Natural, Universidad Pública de Navarra

Campus de Arrosadía, Pamplona, Navarra, 31006, Spain

E-Mail: yuehhsin.lo@gmail.com

Tel: +34948169859

Fax: +34948168930

${ }^{1}$ Deceased. Department of Forest Sciences, University of British Columbia, Vancouver, Canada.

${ }^{2}$ Department of Botany, University of British Columbia, Vancouver, Canada.

${ }^{3}$ Department of Forest Sciences, University of British Columbia, Vancouver, Canada. E-mail: jpkimmins@gmail.com.

${ }^{4}$ Department of Botany, University of British Columbia, Vancouver, Canada.

Current affiliation: Department of Ecology \& Evolutionary Biology, University of Toronto,

Toronto, Canada. E-mail: benjamin.gilbert@utoronto.ca

${ }^{5}$ Departamento de Ciencias del Medio Natural, Universidad Pública de Navarra, Pamplona, Spain. E-mail: juan.blanco@unavarra.es

${ }^{6}$ Department of Forest Sciences, University of British Columbia, Vancouver, Canada.

Current affiliation: Departamento de Ciencias del Medio Natural, Universidad Pública de

Navarra, Pamplona, Spain. E-mail: yuehhsin.lo@gmail.com 


\section{Abstract}

We examined two measures of shade tolerance (survival and growth) of planted 1-year-old seedlings of western redcedar (Thuja plicata (Donn ex D. Don)), western hemlock (Tsuga heterophylla ([Raf.] Sarg.)) and amabilis fir (Abies amabilis ([Dougl. ex Loud] Dougl. ex Forbes)). Seedlings were planted at two different sites (forest interior: $4.5 \%$ mean above canopy photosynthetically active radiation [ACPAR], and forest edge: 41.5\% mean ACPAR), in a 90year-old, windthrow origin, unmanaged mesic western hemlock-amabilis fir stand. Seedlings were planted in 1997, and re-measured in 1998 and 2001 (after five growing seasons). To assess the effects of deer browsing on redcedar survival and growth, additional seedlings of this species were planted and protected with Vexar@ tubes. To examine for nutrient-light interactions, half of these seedlings were fertilized with N-P-K and micronutrients at planting. Western redcedar had high levels of survival after 4 years (98\% in edge plots and 93\% in interior plots). Redcedar seedlings in edge plots were more vigorous but were browsed more heavily than in the interior plots. At edge sites, the negative effects of the Vexar@ tubes may have been lower than their positive effects. Hemlock survival was about $50 \%$ in the stand interior but $80 \%$ in the edge plots. Amabilis fir in the interior plots had the lowest survival of the three species, with only $40 \%$ of initial seedlings surviving over the next four years, but had high survival in edge plots (95\%). Height, biomass, and root collar diameter growth were significantly higher in edge plots for fir and hemlock. However, for redcedar, only biomass was significantly higher and no differences were detected for height and diameter. Our results show that shade tolerance cannot be assessed by simple measures of leaf/light relationships alone, but also requires consideration of light, nutrition, growth and browsing.

Keywords: light tolerance, light-nutrient interactions, edge effects, seedling survival, seedling growth. 


\section{Introduction}

An ongoing trend for the last decade is driving forest management away from clearcutting and planting towards partial and variable retention harvesting with natural regeneration (Gustafsson et al. 2012), based on concerns about biological diversity (Lindenmayer and Franklin 2002, Fedrowitz et al. 2014), hydrological issues (Hartman 2004), ecosystem function (Lindenmayer et al. 2012), and public antipathy towards the aesthetics of clearcut harvesting (Sheppard and Harshaw 2000). Partial harvesting systems inevitably increase the role of natural regeneration, but planting will likely be necessary for desired species with unreliable seed production, heavy seed predation, lack of a seed source or inadequate seedbed/germinant establishment conditions. Therefore, silvicultural systems with natural regeneration, augmented where needed by planting, have been promoted or suggested over the last two decades (Arnott and Beese 1997, Serrouya and D’Eon 2004, Nilsson et al. 2006, Bott et al 2014, Bragg et al 2015, Antos et al. 2016).

Success of both natural regeneration and planting in partial harvesting and variable retention systems requires knowledge of shade tolerance (Wright et al. 1998b) and the associated belowground competition for soil resources. Shade tolerance is a multi-dimensional concept (Dean 2012, Lienard et al. 2015), and simple photosynthetic light saturation curves do not adequately define it (Wright et al. 1998b, Valladares and Niinemets 2008, Lienard et al. 2015). Prediction of successional pathways requires an understanding of what it means for one plant species to establish and grow in the shade of another (Weber et al. 2014). Basing such predictions only or even mainly on light, as is the case in many process-based forest models (see reviews by Lo et al. 2011, 2015, and references therein) can lead to erroneous conclusions, if other factors are not accounted for (Kimmins et al. 2008, Blanco et al. 2015, Dybzinski et al. 2015). Carbon allocation shifts in response to soil resource availability (Franklin et al. 2012, 
Farrior et al. 2013) can have significant effects on interspecific competition and successional pathways (Weber et al. 2014). Seedling establishment is a key process that involves multiple biotic and abiotic factors (Blanco et al. 2009). Therefore, ecosystem-level models are vital for the development of adaptive, flexible decision support tools for sustainable forest management (Messier et al. 2003; Kimmins et al. 2010). Credible mechanistic process models of ecosystem response to natural and management-induced disturbance (Perrera et al. 2004) at the stand and landscape scale (Seely et al. 2004) cannot be developed without this knowledge, as the minimum complexity needed to represent the main processes that affect tree growth is not reached (Kimmins et al. 2008).

Complex interactions between factors affecting seedling survival have been studied in forests on northeastern Vancouver Island. Weber et al. (2003) compared the relative performance of the three species studied in this paper in similar site conditions and light environments grown from seed. Also, a study of the role of mycorrhizae in determining germinant shade tolerance was carried out (Weber et al. 2005), as well as an assessment of what the results of all these studies mean for successional pathways in these forests (Weber et al. 2014). Other previous studies in the area have reported the growth of western hemlock and redcedar in different light environments (Carter and Klinka 1992, Wang et al. 1994, Drever and Lertzman 2001, Karakatsoulis 2004). Klinka et al. (1992) reported the response of amabilis fir.

Recently, Leidner et al. (2015) have offered a review of the shade tolerance concept in which the tree species studied here are all ranked as "very tolerant", but on the other hand, McKenzie and Tinker (2013) have shown that at least western redcedar can behave as a pioneer species. Therefore, traditional forest management of these forests needs to be revisited and updated in view of the recent findings on forest ecology (Antos et al. 2016). Particularly, traditional management experience in these forests indicates that there are marked differences among the three species, assuming that the shade tolerance sequence follows the pattern: 
amabilis fir $\geq$ western redcedar > western hemlock. In addition, our team's previous research has shown that shade tolerance of seedlings and adult trees can be different, at least for western redcedar (Weber et al. 2003, 2005), and that such inter-specific differences in shade tolerance can have important successional consequences (Weber et al. 2014). Bringing light to such issues has been highlighted as one of the main points for future research at these sites (Antos et al. 2016).

Therefore, our general objective was to test if a multi-variable response of the seedlings of these three species supports traditional light-related measures of shade tolerance for western redcedar (Thuja plicata [Donn ex D. Don]), western hemlock (Tsuga heterophylla [[Raf.] Sarg.]) and amabilis fir (Abies amabilis [Dougl. ex Loud] Dougl. ex Forbes)) seedlings planted in two contrasting light environments (forest edge and forest interior) in western hemlock-amabilis fir (HA) stands on northeastern Vancouver Island, British Columbia. To reach this goal, our specific objectives were to test: 1 ) if shade tolerant conifer species have different survival rates in the shade; 2) if shade tolerant conifer species show different height growth responses across a gradient of light conditions; and 3) if shade tolerant conifer species maintain or reduce their height:diameter ratios as light levels decline.The information provided by these tests allowed us to establish a ranking of shade tolerance for three major forest species in western Canada.

\section{Materials and Methods}

This study was part of a larger study of the successional pathways on northeastern Vancouver Island (Weber et al. 2003, 2005, 2014). Succession in these ecosystems has generally been interpreted in terms of wind-related disturbance, light competition and relative shade tolerance. However, the SCHIRP study (Salal-Cedar-Hemlock Integrated Research Project; Prescott and Weetman 1994), of which this study is a component, was undertaken to expand the scope of successional investigations in these forests to the ecosystem level, including nutrition 
and various biotic interactions. To address the objectives, nursery-stock seedlings were planted in interior and edge plots of western hemlock (Tsuga heterophylla) - Pacific silver fir (Abies amabilis) stands (HA) stands and their survival and growth were measured over five years. Secondarily, since we were interested in factors limiting redcedar recruitment in HA stands as detected by Weber et al. (2003), we tested whether redcedar seedling survival and growth was affected by nutrient availability or browsing damage. Such a test was done by including an additional factorial experiment on treatments of fertilizer and browsing protection for redcedar seedlings

\subsection{Research sites}

In 1997, four sites were selected at random from the population of HA stands bordering recent clearcuts within the Port McNeill $\left(50^{\circ} 35^{\prime} 25^{\prime \prime} \mathrm{N}, 127^{\circ} 05^{\prime} 5^{\prime \prime} \mathrm{W}\right)$ forest area of Tree Farm License 6, a 170,000 ha region on northeastern Vancouver Island. Elevation ranged from 300 to 600 m.a.s.l. Slope was minimal $(<10 \%)$ on all stands, and consequently aspect was not controlled. Meteorological data from the Port Hardy airport (approximately $15 \mathrm{~km}$ north of the study area) showed a mean annual precipitation of $1,700 \mathrm{~mm}$, with most of this occurring in the winter months (Keenan et al. 1993). Mean daily temperatures range from $2.4^{\circ} \mathrm{C}$ in January to $13.8^{\circ} \mathrm{C}$ in August.

Selected sites were all in the Submontane Very Wet Maritime Variant (CWHvm1) of the Coastal Western Hemlock biogeoclimatic zone (Krajina 1965, modified by Pojar et al, 1987). Selected stands were representative of zonal sites and were dispersed throughout the study area. HA sites are classified as poor-to-medium in nutrient regime and fresh-to-moist in moisture regime (Pojar et al. 1987). The average mass of forest floor in HA stands is $211 \mathrm{Mg} \mathrm{ha}^{-1}$ (Keenan et al. 1993). Soils are typically humo-ferric podzols with $0.25 \mathrm{~m}$ of mor humus (combined LFH 
layers) overlying surficial unconsolidated morainal and fluvial outwash material (Sajedi et al. 2012).

In early 1997, four sites were selected. The major disturbance that initiated the studied stands was a windstorm in 1908 that affected about 30,000 ha (Prescott et al. 1993). As a consequence, the stands selected were even-aged and about 90 years old at the start of the experiment in 1997. At each of the four sites, four plots were established at the stand edge (just inside the canopy, within the canopy dripline) and four in the interior of the forest (defined as 50 $\mathrm{m}$ from the stand edge). Each plot contained 24 seedlings, for a total of 768 seedlings per species used in the experiment. All plots had heterogeneous microtopography, with the ground mounded due to a history of periodic stand replacing wind disturbances, resulting in variable depths of forest floor over mineral soil. Mound heights were 30-100 cm and spaced at approximately 2 to 6 m.

The forest interior plots contained a very sparse ( $0-3 \%$ cover) understory of salal (Gaultheria shallon Pursh), deer fern (Blechnum spicant L. Roth), blueberry (Vaccinium ovalifolium Sm.) and salmonberry (Rubus spectabilis Pursh). The forest edge plots had more abundant and vigorous herb and shrub layers ( $0-15 \%$ cover) of the same species plus occasional fireweed (Epilobium angustifolium L.). Both the interior and edge had a consistent cover (70100\%) of mosses, mainly Hylocomium splendens (Hedw.) and Rhytidiadelphus loreus (Hedw.), with lesser amounts of Plagiothecium undulatum (Hedw.). Clearcut areas adjacent to the selected stands had almost no moss cover, but 50-80\% cover of herbs, shrubs and young (7 to 12 -yearold) trees. The main plant species present in the clearcuts were fireweed, salal and salmonberry.

\subsection{Silvicultural treatments}

One-year-old nursery stock seedlings grown from local seed sources of redcedar, amabilis fir and hemlock were planted in April 1997 in each plot at each site. Height, root collar 
diameter, and total dry weight were measured at the time of planting for a random sample of 30 individuals of each species. Seedlings were planted at least $1 \mathrm{~m}$ apart, avoiding microsites with rotten wood and exposed mineral soil. Vegetation within $50 \mathrm{~cm}$ of each seedling was removed manually twice during the first year to reduce direct competition.

For redcedar only, fertilization and browsing protection treatments (using Vexar@ collars) were applied in factorial combination (fertilization, browsing protection, and fertilization plus browsing protection). Untreated seedlings from the main experiment acted as controls. Fertilization was done at the time of planting with "teabags" filled with fertilizer (Biopak 16-6-8 NPK plus micronutrients, 12-month release of plant nutrients). Ten-cm diameter plastic Vexar(C) tubing was used to prevent deer browsing. We used four seedlings for each of the three treatments at each of the four plots at each location (edge, interior) at each of the four sites for a total of 384 additional redcedar seedlings. Initial size and mass values of seedlings were measured at planting time (Table 1).

\subsection{Survival and growth measurements}

Seedling survival, height, and root collar diameter were assessed in the winter of 1997, May 1998, February 1999, and at the end of the experiment in May 2001, when aboveground biomass was harvested, dried at $65^{\circ} \mathrm{C}$ for $48-60$ hours (until constant mass) and weighed. Limited project resources did not permit the recovery of below-ground biomass.

Light measurements were conducted during overcast conditions on May 30, 2001 using the instantaneous, one point technique described by Parent and Messier (1996). Two calibrated sunfleck ceptometers (model SF-80, Decagon Devices, Inc., Pullman, Washington) were used to simultaneously measure the photosynthetic photon flux density (PPFD) at the height of the seedlings in all experimental plots and in adjacent open areas (clearcuts). Two measurements were taken at $90^{\circ}$ to each other at two locations in each plot, with the person taking the 
measurements standing to the north of the ceptometer. The percentage of above canopy photosynthetically active radiation (\% ACPAR) at each experimental plot was recorder as:

$$
\% A C P A R_{\text {experimental unit }}=\frac{\overline{P P F D}_{\text {experimental unit }}}{P P F D_{\text {open field }}} \times 100
$$

\subsection{Data analysis}

Data were analysed using Proc-GLM (SAS version 8.2, SAS Institute Inc., Cary, North Carolina) as a split-plot blocked design, with four blocks (sites), the whole plot-factor being plot location (edge and interior) and the subplot factor being tree species. For the additional redcedar experiment, the subplot was a factorial experiment of fertilization and herbivore browse protection. There were some missing values in the data set due to disturbance by bears and windthrow of overstory trees. An alpha value of 0.05 was considered significant for all analyses. Where significant interactions occurred, analysis of variance was followed by pairwise $t$-test comparisons of the least-square means within each of the treatment effects, with the alpha level adjusted for the number of comparisons using Bonferonni's adjustment (Quinn and Keough 2002).

Percent survival in the main experiment was calculated from the 16 individuals of each species/treatment combination at each location at each site. Survival data were arcsinetransformed previously for statistical analysis to meet the assumptions of normality and homogeneity of variance, but all results are presented in the original units. Mean seedling size measurements for each treatment at each location were calculated at the plot level from seedlings that survived through the end of the study, which gives $n=4$ in the statistical analyses.

\section{Results}

\subsection{Seedling survival}


As expected, the interior and edge plots had substantially different light environments. Interior plots had consistently low light levels (ACPAR $4.5 \pm 2.3 \%$, mean \pm s.d.). Edge plots had consistently higher light levels but were much more variable (ACPAR 41.5 $\pm 20.2 \%$ ) due to aspect and stand structure variation.

Initial survival of planted seedlings after the first growing season differed among the species and for the two light treatments (Figure 1, top panel). Redcedar and hemlock both had high first-year survival rates in edge and interior plots $(100.0 \pm 7.5 \%$, and $99.1 \pm 2.4 \%$ for redcedar; $93.9 \pm 5.4 \%$ and $98.4 \pm 12.2 \%$ for hemlock, respectively); amabilis fir had high survival in edge plots $(97.6 \pm 9.6 \%)$ but much lower survival in the stand interior $(59.1 \pm 31.4 \%)$. At the time of harvest in May 2001, four growing seasons after the first assessment, survival for the whole 1997-2001 period remained uniformly high for redcedar in both interior and edge locations. Hemlock had lower and somewhat more variable survival than redcedar in edge plots, and much lower and more variable survival in interior plots. Fir had high survival in edge plots but very low survival in interior plots (Table 2).

To eliminate carryover nursery effects and mortality that may have been due to initial transplant shock regardless of the treatments, we estimated the proportion of trees alive at the end of the first growing season that survived through to the end of the study (1998-2001 survival) (Figure 1, bottom panel). There was a significant interaction between species and location. In interior plots there was a significant difference between the species $(p=0.003)$, with redcedar survival $(94.8 \pm 3.4 \%)$ being greater than that of hemlock $(50.1 \pm 31.5 \%)$ or fir $(41.9 \pm$ 27.9\%). We did not detect a significant difference in 1998-2001 survival among species in edge plots $(p=0.083)$, although hemlock survival tended to be lower than that of redcedar and fir. Both hemlock and fir had lower survival in interior than in edge plots.

Although redcedar had uniformly high survival in both edge and interior plots, there was a small but statistically significant reduction in survival for seedlings with the browsing 
protection treatment in interior plots $(p=0.042)$. We did not detect a significant effect of fertilization on redcedar survival (Figure 2).

\subsection{Seedling growth: height, diameter, and aboveground biomass}

Initial mean seedling size was similar for redcedar and hemlock, but fir seedlings were shorter, had larger root collars and greater biomass (Table 1). Height growth for the period 19982001 was not significantly different in edge and interior plots for redcedar, but both fir and hemlock had much greater height growth in edge than in interior plots (Table 3, Figure 3 top panel). Hemlock and fir had much greater root collar diameter growth in the period 1998-2001 in edge than in interior plots, but there was no significant difference for redcedar (Figure 3, central panel). These growth measurements undoubtedly underestimated the 1997-2001 growth, particularly for seedlings in edge plots, but we rejected the first year growth response to avoid nursery carryover effects and any planting shock. Fir showed a reduction in height:diameter (H/D) ratio from edge to interior plots, whereas redcedar, and hemlock showed an increase, suggesting a shade tolerance ranking of fir $>$ redcedar $>$ hemlock (Table 4$)$.

The difference between aboveground mass in 2001 and the mean initial mass of a subsample of seedlings (Table 1) was averaged for each position in each site. Both hemlock and fir had significantly greater aboveground biomass increases in edge than interior plots $(p<$ 0.001), and the effect for redcedar was marginally significant ( $p=0.053$ ) (Figure 3, bottom panel). The slight decrease in mass for fir seedlings in the stand interior suggests greater survival of smaller seedlings, mortality of plant parts (e.g. leader death, needle loss) or a combination of both.

\subsection{Effects of fertilization and browsing protection on redcedar growth}


Redcedar growth in response to fertilization and browsing protection treatments depended on the plot location. Height and aboveground biomass significantly increased in response to fertilization in edge plots, but we did not detect an effect in interior plots (Figure 4). Seedling height growth was significantly greater in edge than interior plots for fertilized treatments, but there was no significant difference for unfertilized treatments. Root collar diameter and aboveground mass growth was greater in edge than interior plots for both fertilized and unfertilized treatments. In interior plots, browsing protection resulted in a decrease in mean root collar diameter and aboveground mass relative to control seedlings. Browsing protection resulted in significantly greater growth in height, root collar diameter and aboveground mass in edge than in interior plots (Figure 4). The decrease in mean aboveground mass in fertilized, interior redcedar seedlings with browsing protection over the 1997-2001 period (Figure 4, bottom panel) contrasts with their increase in height and root collar diameter over the 1998-2001 period (Figures 4, top and central panels), suggesting greater mortality of larger redcedar seedlings in the browsing protection treatment over the first year.

\section{Discussion}

\subsection{Seedling survival}

The light levels (percentage of ACPAR) for this study are similar to the values reported in nine other similar HA stands in the study area by Weber et al. (2003), who reported 4\% and 32 to $37 \%$ for interior and edge plots, respectively. Shade tolerant species do not respond strongly to increases in light when there are high light levels, in contrast to shade intolerant species that respond little to light increases at low levels, but strongly to increases at higher levels (Kobe and Coates 1997, Mailly and Kimmins 1997). Additionally, Karakatsoulis (2004) reported little difference in height and H/D ratio of 1-year-old western hemlock and redcedar seedlings grown in the greenhouse for four months at $24 \%$ and $45 \%$ full light. Natural variability in light levels 
along stand edges is therefore not expected to affect survival and growth response of these shade tolerant species.

Planted redcedar seedlings survived well but grew slowly everywhere, a result that is consistent with their reputed tolerance of shade but slow early growth, especially in the shade (Carter and Klinka 1992, Kobe et al. 1995, Kobe and Coates 1997, Khan et al. 2000, Antos et al. 2016). Hemlock survival beyond the first year was only about $50 \%$ in interior plots in contrast to over $80 \%$ in edge plots. Similar mortality rates for planted hemlock seedlings were reported by Mailly and Kimmins (1997). However, these authors also indicated that hemlock mortality rates were independent from light levels. In our case, hemlock growth was very slow in interior plots and much greater in edge plots. Coates (2000) also showed that for redcedar, hemlock, and fir small gaps could noticeably increase growth rates of planted seedling. Karakatsoulis (2004) also reported better growth for hemlock in open conditions. Fir in interior plots had the lowest survival of the three species but had very high survival (similar to hemlock and slightly higher than redcedar) in edge plots. Fir seedlings that survived in the interior grew very little while those on the edge had growth intermediate between redcedar and hemlock (Table 2).

The comparison of our results to those of Weber et al. (2003) (Table 2) suggests that shade tolerance based on survival of planted seedlings may be very different from that of natural regeneration from seed. Similarly, Holgén and Hågen (2008) also found that differences between naturally regenerated and planted seedlings depended on microsite features in northern forests. In our sites, planted fir seedlings had higher survival than regenerated seedlings in edge plots, but the reverse was true in the interior plots. The difference in survival between edge and interior was also much greater for planted than seed origin seedlings. Hemlock planted seedlings had higher survival than seed origin seedlings in both locations, with a generally similar decline in survival between edge and interior plots. The uniformly high survival of planted redcedar seedlings at both locations contrasted dramatically with the low and very low survival in edge 
and interior plots, respectively. This was attributed to mycorrhizal factors by Weber et al. (2003). Although not studied, we expect that the planted seedlings would be mycorrhizal, given their high responsiveness to the presence of mycorrhizae propagules in the soil (Kough et al. 1985). With shade tolerant secondary foliage, the redcedar seedlings would be able to support the arbuscular symbionts. Belowground competition has also been identified as one of the main factors influencing natural regeneration in thinned forests in the Pacific Northwest (Devine and Harrington 2008).

Based on survival, redcedar was the most tolerant of the three species when planted, with only $5 \%$ reduction from edge to interior. This is probably due to redcedar's plasticity to adapt its growth rates to different and varying light levels. Karakatsoulis (2004) showed redcedar's capability to growth under low light levels that changed seasonally, including the capability to use sunflecks. Fir was the least tolerant of the shaded stand conditions, with a $75 \%$ reduction in survival. Hemlock was intermediate with a $40 \%$ reduction. This contrasts with seedlings developing from seed placed on the forest floor (Weber et al. 2003), which ranked in the order hemlock $>$ fir $>$ redcedar (Table 2). The difference between planted and regenerated survival could also be related to seed size and size predation, as seed size for the same species follows the same rank as survival (hemlock > fir > redcedar), and it has been reported that bigger seeds have higher survival rates (Westoby et al. 2002, Lo et al. 2012). However, the rank for survival of planted seedlings was different (fir $>$ hemlock $>$ redcedar), indicating that the influence of seed size on mortality rates could be overrun if they are grown in nurseries, probably as seed predation much more controlled.

Redcedar seedlings did not have a clear significant response to fertilization alone. This could indicate that soil nutrient availability is not by itself an important issue for promoting regeneration for this species, especially if seedlings were mycorrhizal. Similar results have been reported for other tree species in the same region (Lilles et al. 2014). However, fertilization and 
browsing protection combined improved redcedar growth in edge plots, suggesting that both browsing and fertility are limiting factors on growth under non-limiting light conditions when occurring together, which is the normal situation in the field.

In contrast, treatments with only browsing protection caused a reduction in survival, root collar growth, and mass growth in interior plots. Possible explanations for this include: 1) physical interference with seedling growth by Vexar@ tubes; 2) additional shading caused by the Vexar@ tubes (Puértolas et al. 2010, Vázquez de Castro et al. 2014), which would have been more detrimental to the seedlings in interior than edge plots; and 3) differences among species in severity of browsing of unprotected redcedar seedlings, which tends to be greater at stand edge than stand interior locations. Browsing by deer may have been a significant factor in the low response of unprotected redcedar seedlings to edge light environments. Black-tailed deer (Odocoileus hemionus Rafinesque) could also be a factor removing redcedar seedlings (Stroh et al. 2008). Hemlock and fir are much less subject to deer browsing so they can respond to greater resource availability at the stand edge. However, growth of redcedar seedlings with fertilization and browsing protection was still substantially lower than hemlock growth in edge plots. This indicates the inherent differences between species in growing rates.

\subsection{Seedling height growth}

In interior plots, redcedar and hemlock height growth was quite similar and fir had the lowest rate (Table 3). Fir seedlings were also shorter than hemlock and redcedar at the time of planting (Table 1), indicating that taller plants may have had higher mortality rates. However, seedlings had nearly twice the mass and significantly greater root collar diameter, pointing to relative higher importance of secondary (diameter) growth rather than primary (height) growth. Amabilis fir is known to respond to deep shade by reducing height growth in favour of branch elongation, and stem and root diameter growth (Kimmins 2004, Antos et al. 2005). Shade intolerant species 
maintain height growth in the shade at the expense of diameter and root growth (Kobe and Coates 1997, Mailly and Kimmins 1997, Karakatsoulis 2004). In edge plots, hemlock had the greatest height growth, followed by amabilis fir, with redcedar the lowest. In terms of relative reduction in height growth from edge to interior, the three species ranked fir $>$ hemlock $>$ redcedar, with redcedar actually being taller in the interior plots (Table 3).

Growth of redcedar seedlings was similar at edge and interior locations unless accompanied by any of the silvicultural treatments tested. Fertilization increased redcedar height growth in edge plot, suggesting that its growth was nutrient limited in this location. In interior plots fertilization had no effect, suggesting that light was the dominant limiting factor. Browsing protection increased the growth in edge plots, probably because of reduced herbivory (Stroh et al. 2008). On the other hand, Vexar@ reduced growth in interior plots probably by further reducing light reaching the foliage, and this was intensified by fertilization. Even with the additional treatments, redcedar growth was always much less than that of hemlock. The results from the browsing protection treatments suggested that at the edge locations, redcedar response was in part due to protection from browsing.

The height growth data suggest the following shade tolerance ranking: fir > hemlock > redcedar. This is in conflict with the general assumption by local foresters that redcedar is very shade tolerant, ranking close behind fir. In Karaktsoulis’' (2004) experiment, Douglas-fir (Pseudotsuga menziesii (Mirb.) Franco), which is considered to be a moderately intolerant shade species in the climatic conditions of the study area, showed no significant change in height above $12 \%$ full light, whereas its diameter increased and H/D decreased continuously over the 3-45\% full light gradient. This could indicate that redcedar is less shade tolerant than traditionally assumed, in accordance with observations from natural regeneration (Weber et al. 2005). 


\subsection{Height:diameter ratios}

Height:diameter ratio (H/D) is thought to be a useful measure of shade tolerance (Hulshof et al. 2015). Our results for this parameter agree with the ranking based on height, but puts redcedar much closer to hemlock than to fir. Similarly, results from Karakatsoulis (2004) reported a significant increase in height and root collar diameter for hemlock and redcedar between seedlings grown for 4 months at 3\% full light vs. 24\% full light (Table 4). The further increase from 23 to $45 \%$ full light was non-significant. Levels of 3-45\% full light are similar to the ACPAR range we encountered in this study. Mailly and Kimmins (1997) reported a linear decrease in the H/D ratio with increasing light levels for hemlock.

Fir showed essentially no change in H/D from its initial values. Redcedar sustained its initial value in the edge plots but dramatically increased H/D in the interior plots, a response more typical of a shade intolerant than a shade tolerant species (cf. Douglas-fir, Table 4). Hemlock showed a different response, halving its initial H/D value in the edge plots while maintaining its initial ratio in the interior plots, giving a similar difference in ratio values to that of redcedar. Whether this reflects different nursery light regimes for the two species is not known ${ }^{7}$, but the results could suggest that the hemlock may have been grown at a reduced PAR and redcedar at full light.

Karakatsoulis (2004) found that when grown for 4 months under a range of light levels in the greenhouse, 1-year old seedlings increased in H/D ratio between $45 \%$ full light and $3 \%$ full light as follows: Douglas fir $+82 \%$; hemlock $+19 \%$; and redcedar $+14 \%$ (Table 4 ). These results show a ranking for hemlock and redcedar close to that for height. However, Karakatsoulis' results differ from our results, a fact suggesting again that there are more determinants of seedling growth in our field sites than in the greenhouse experiment reported by Karakatsoulis (2004). The possible effects of differences in seed origin of the seedlings between

\footnotetext{
${ }^{7}$ Nursery information was lost with the sudden death of Adrian Weber.
} 
the two experiments are not known, raising the question as to whether the field results reflect much more than simply light conditions, and greenhouse-based studies of shade tolerance as being an incomplete measure of tolerance. Wright et al (1998a) and Valladares and Niimetes (2008) concluded that survival of samplings is a more important measure of the ability of trees to compete than simple light adaptations, again implying that there are many factors that contribute to the ability of a species to invade, survive and grow with other species.

\subsection{Multi-variable assessment of shade tolerance}

The interspecific differences we detected in growth response are comparable with results of other field studies of light-dependent growth responses (e.g., Carter and Klinka 1992, Wang et al. 1994, Mailly and Kimmins 1997, Coates 1998, Wright et al. 1998b) and are consistent with traditional classifications of shade tolerance, which rank western redcedar as more shade tolerant than Douglas-fir (Lienard et al. 2015). Shade-tolerant species typically grow faster at low levels of light, whereas shade-intolerant species typically grow faster at high light levels (Kobe and Coates 1997, Mailly and Kimmins 1997, Valladares and Niiemets 2008). This was the pattern we observed for height growth and radial growth at low light western redcedar. These results indicate a trade-off in the ability of saplings to survive and grow at low light levels with their ability to grow rapidly at high light levels (Pacala et al. 1994, Kobe and Coates 1997, Wright et al. 1998b, Messier et al. 1999).

Shade tolerance is a multi-dimensional characteristic of a plant species (Kimmins 2004, Valladares and Niiemets 2008, Lienard et al. 2015) that depends on many factors, including PAR levels, photosynthetic light saturations curves for the species, its carbon allocation patterns under low light (which affects its resistance to wind and snow damage), disease resistance, and its ability to establish appropriate mycorrhizal relationships that permit it to compete for soil resources under low light and adverse soil microbial conditions (Weber et al. 2005). 
Kobe (1999) showed that, when considered together, mortality and growth can lead to light gradient partitioning. Neither growth nor mortality considered alone can reveal this specialization. Such light gradient partitioning provides an explanation for successional dynamics in these forests (Weber et al. 2014). Therefore, empirical measures of shade tolerance should include both survival and growth at different light levels.

Franklin and Dyrness (1988) classified redcedar as "tolerant", and amabilis fir and western hemlock as "very tolerant". Linder et al. (2015) have classified all the species as "very tolerant". Lertzman (1995) reported that amabilis fir is more shade tolerant than mountain hemlock in the Mountain Hemlock zone near Vancouver and attributed this to the larger seed and longer radical of the germinant that enable the fir to survive the first summer drying of the surface layers of the forest floor and to develop sufficient leaf area to survive in a deeply shaded understory. However, the lower survival of both hemlock and amabilis fir seedlings in the interior plots indicate that planted seedlings of these two species are actually less tolerant than planted redcedar, in wetter and colder sites in the interior of HA forests on northern Vancouver Island,.

High survival of redcedar seedling with secondary foliage over the five years of this study indicates that planted seedlings of this species can tolerate the conditions in both the interior and edge plots of these forests. In contrast, Weber et al. (2003) reported little natural recruitment of redcedar seedlings into closed HA stands, while hemlock and amabilis fir successfully recruit given a seed source and some opening of the canopy. The failure of redcedar to recruit is attributed to the relative shade intolerance of redcedar germinants that have a low leaf area of primary leaves, and appear to require higher light levels for survival and the development of shade tolerant secondary foliage than that found in closed HA stands (Weber et al. 2005). These authors attributed the lack of redcedar recruitment into closed, mature HA stands to the domination of the upper soil by ectotrophic mycorrhizae and the exclusion of arbuscular fungi that redcedar germinants need in order to compete for nutrients with the ectotrophic fine roots of 
overstory hemlock and amabilis fir. Antos et al. (2016) have also pointed to mycorrhizae as one determining factor in the ecology of western redcedar. These nutrients are required in order to develop the shade tolerant secondary foliage that confers on redcedar seedlings the shade tolerance observed in the present study (Weber et al. 2003). Western redcedar can also benefit from mycorrhizae by supporting a larger root mass compared to hemlock and fir. Redcedar is therefore able to mobilize more nutrients (Hawkins et al. 2014). However, the growth response to mycorrhizae in seedlings can also be affected by light levels (Gehring 2003).

Based on survival of the planted seedlings, shade tolerance would appear to be in the order redcedar $>$ hemlock $>$ fir. This contrasts with observed natural regeneration in HA stands which suggests shade tolerance for natural regeneration in the order fir $>$ hemlock $>$ redcedar (Table 5). Survival of seedlings established experimentally from seed (on forest floor substrate) in interior and edge plots of HA forests was found to decline in the order of fir > hemlock > redcedar after 2.5 years (Weber et al 2003). Differences in results between these two studies suggest that survival of these species depends on size (or development stage in the case of redcedar - the presence or absence of secondary foliage) or may relate to differences between planted nurserystock seedlings and seedlings regenerated from seed (Holgén and Hållen 2008).

Hemlock and fir had substantially greater growth in edge plots than interior, which is consistent with the growth strategy of plants that are less shade-tolerant and have higher light saturation points for photosynthesis. This strategy would lead to a greater increase in net productivity as PAR level increase compared to a shade tolerant species. Based on this observation shade tolerance would be redcedar $>$ fir $>$ hemlock.

Redcedar and hemlock seedlings in interior plots had relatively greater height growth than biomass production. This phenomenon suggests etiolation, a feature of shade intolerant plants, although some foliage loss due to planting shock could also have happened. This would suggest a shade tolerance ranking of fir $>$ hemlock $>$ redcedar. Compared to interior forest conditions, 
redcedar germinants had higher survival rates at stand edge and clearcut locations, including low light environments beneath evergreen shrub foliage in clearcuts (Weber et al. 2003, Antos et al. 2016). Redcedar's ability to survive in shade appears to be strongly related to the development of secondary foliage (Weber et al. 2003), which could be used to take advantage of sunflecks and is adapted to variable light levels along short time scales such as days or seasons (Karakatsoulis 2004). Early growth and development appears to play a critical role in establishment and longterm recruitment of the species on a site, with implications for successional pathways (Weber et al 2014). The very low growth of cedar in edge plots found in our study differs from the results of other studies (Coates and Burton 1999, Khan et al. 2000, MacKenzie and Tinker 2013).This fact suggests that there are other factors more important than light affecting the growth but not survival of planted redcedar.

\section{Conclusions}

When all the studied parameters are combined to set up a simple ranking of shade tolerance, all species are close to each other but the ranking appears to be amabilis fir > western redcedar > western hemlock (Table 5), supporting our initial hypothesis and traditional knowledge. However, our results for the three species combined with the factorial analysis of silvicultural treatments for western redcedar indicate that while light is undoubtedly important, factors other than shade are important for both early survival and subsequent growth.

\section{References}

Antos, J.A., Guest, H.I., and Parish, R. 2005. The tree seedling bank in an ancient montane forest: stress tolerators in a productive habitat. J. Ecol. 93(3): 536-543.

Antos, J.P., Filipescu, C.N., Negrave, R.W. 2016. Ecology of western redcedar (Thuja plicata). Implications for management of a high-value multiple-use resource. For. Ecol. Manage. 375: $211-222$. 
Arnott, J. T. and W. J. Beese. 1997. Alternatives to clearcutting in BC coastal montane forests. Forestry Chronicle. 73: 670-678.

Blanco J.A., Welham C., Kimmins J.P., Seely B., Mailly D. 2009. Guidelines for modeling natural regeneration in boreal forests. The Forestry Chronicle. 85(3), 427-439.

Blanco J.A., González de Andrés E., San Emeterio L., Lo Y.H. 2015. Modelling mixed forest stands: methodological challenges and approaches. In: Park Y.S., Lek S., Baehr C., Jorgensen S.E. (Eds.) Advanced Modelling Techniques Studying Global Changes in Environmental Sciences. Elsevier, Amsterdam, The Netherlands. Pp. 186-223. ISBN 9780-444-63-536-5.

Bott, R.D., Murphy, P.J. and Udell, R., 2014. Growing the new forest - The evolution of applied silviculture in Alberta. Forestry Chronicle, 90(3): 324-329.

Bragg, D.C., Schuler, J.L., Pelkki, M.H., Scott, D.A. and Guldin, J.M., 2015. More than just timber: silvicultural options and ecosystem services from managed southern pine stands. General Technical Report - Southern Research Station, USDA Forest Service (SRS-203): 411-418.

Carter, R. E. and Klinka, K. 1992. Variation in shade tolerance of Douglas fir, western hemlock, and western red cedar in coastal British Columbia. Forest Ecology and Management 55: 87-105.

Coates, K.D. 2000. Conifer seedling response to northern temperate forests gaps. For. Ecol. Manage. 127:249-269.

Coates, K. D. and Burton, P. 1999. Growth of planted tree seedlings in response to ambient light levels in northwestern interior cedar-hemlock forests of British Columbia. Canadian Journal of Forest Research 29: 1374-1382.

Dean, T.J. 2012. A simple case for the term "tolerance". J. For. 110: 463-464.

Devine, W.D., Harrington, T.B. 2008. Belowground competition influences growth of natural regeneration in thinned Douglas-fir stands. Can. J. For. Res. 38: 3085-3097.

Dybzinski, R., Farrior, E.C., Pacala, S.W. 2015. Increased forest carbon storage with increased atmospheric $\mathrm{CO}_{2}$ despite nitrogen limitation: a game-theoretic allocation model for trees in competition for nitrogen and light. Glo. Chan. Biol. 21: 1182-1196.

Drever C. R. and K. P. Lertzman. 2001. Light-growth responses of coastal Douglas-fir and western redcedar saplings under different regimes of soil moisture and nutrients. Can. J. For. Res. 31: 2124-2133. 
Farrios C.E., Tilman, D., Dybzinski, R., Reich, P.B., Levin, S.A., Pacala, S.W. 2013. Resource limitation in a competitive contect determines complex plant responses to experimental resource additions. Ecology 94: 2505-2517.

Fedrowtiz, K., Koricheva, J., Baker, S.C., Lindenmayer, D.B., Palik, B., Rosenvald, R., Beese, W., Frnaklin, J.F., Kouki, J., Macdonald, E., Messier, C., Sverdrup-Thygeson, A., Gustafsson, L. 2014. Can retention forestry help conserve biodiversity? A meta-analysis. J. Applied Ecol. 51: 1669-1679.

Franklin, J. F., D. R. Berg, D. A. Thornburgh and J. C. Tappeiner. 1997, Alternative silvicultural approaches to timber harvesting: variable retention harvest systems. pp 111-139, K. A. Kohm and J. F. Franklin (eds.) Creating a Forestry for the $21^{\text {st }}$ Century. The Science of Ecosystem Management. Island Press, Washington, DC.

Franklin, J.F. and Dyrness, C.T. 1988 Natural vegetation of Oregon and Washington. Oregon State University Press, Corvallis, OR.

Franklin, O., Johansson, J., Dewar, R.C., Dieckmann, U., McMurtrie, R., Brännström, A., Dybzinski, R. 2012. Modeling carbon allocation in trees: a search for principles. Tree Physiol. 32: 648-666.

Gehring CA (2003) Growth responses to arbuscular mycorrhizae by rain forest seedlings vary with light intensity and tree species. Plant Ecology 167:127-139.

Hartman, G. F. 2004. Effects of forest management activities on watershed processes. Pp 271302. In. T. G. Northcote and G. F. Hartman. Fishes and Forestry. Worldwide Watershed Interactions and Management. Blackwell Science, Oxford, UK.

Gustafsson L., Baker S.C., Bauhus J., Beese W.J., Brodie A., Kouki J., Lindenmayer D.B., Löhmus A., Martínez Pastur G., Messier C., Neyland M., Palik B., Sverdrup-Thygeson A., Volney W.J.A., Wayne A., Franklin J.F. 2012. Retention forestry to maintain multifunctional forests: a world perspective. BioScience 62, 633-645.

Hawkins, B.J., Robbins, S., Porter, R.B. 2014. Nitrogen uptake over entire root systems of tree seedlings. Tree Physiol. 34: 334-342.

Holgén, P., Hånell, B. 2008. Performance of planted and naturally regenerated seedlings in Picea abies-dominated shelterwood stands and clearcuts in Sweden. For. Ecol. Manage. 127: 129-138.

Hulshof, C.M., Swenson, N.G., Weiser, M.D. 2015. Tree height-diameter Allometry across the United States. Ecol. Evol. 5: 1193-1204. 
Karakatsoulis, J. 2004. The growth and photosynthetic response of under-planted conifer seedlings to changes in understory light environment. $\mathrm{PhD}$. Thesis, Univ. of British Columbia, Vancouver, BC. 188 pp.

Keenan, R. 1993. Structure and function of western red cedar and western hemlock forests on northern Vancouver Island, British Columbia. Ph.D. dissertation. Forest sciences department, University of British Columbia, Vancouver, BC. 167 pp.

Khan, S., Rose, R., Haase, D. and Sabin, T. 2000. Effects of shading on morphology, chlorophyll concentration, and chlorophyll fluorescence of four Pacific Northwest conifer species. New Forests 19: 171-186.

Kimmins J.P. 2004. Forest ecology: a foundation for sustainable forest management and environmental ethics in forestry. Prentice Hall, New Jersey. 720 pp.

Kimmins J.P., Blanco J.A., Seely B., Welham C., Scoullar K. 2008. Complexity in Modeling Forest Ecosystems; How Much is Enough? Forest Ecology and Management, 256(10), 1646-1658.

Kimmins J.P., Blanco J.A., Seely B., Welham C., Scoullar K. 2010. Forecasting Forest Futures: A Hybrid Modelling Approach to the Assessment of Sustainability of Forest Ecosystems and their Values. Earthscan Ltd. London, UK. 281 pp. ISBN: 978-1-84407-922-3.

Klinka, K., Wang, Q., Kayahara, G.J., Carter, R.E., and Blackwell, B.A. 1992. Light-growth response relationships in Pacific silver fir (Abies amabilis) and subalpine fir (Abies lasiocarpa). Can. J. Bot. 70: 1919-1930.

Kobe , R.K. 1999. Light gradient partitioning among tropical tree species through differential seedling mortality and growth. Ecology 80: 187-201.

Kobe, R.K., and Coates, K.D. 1997. Models of sapling mortality as a function of growth to characterize interspecific variation in shade tolerance of eight tree species of northwestern British Columbia. Can. J. For. Res. 27: 227-236.

Kobe, R., Pacala, S.W., Silander, J.A., Jr., and Canham, C.D. 1995. Juvenile tree survivorship as a component of shade tolerance. Ecol. Appl. 5: 517-522.

Kough J, Molina R, Linderman R (1985) Mycorrhizal responsiveness of Thuja, Calocedrus, Sequoia and Sequoiadendron species of western North America. Can J For Res 15:10491054

Krajina, V. J. 1965. Biogeoclimatic Zones of British Columbia. Ecol. West. N. America. (Dept. Bot., Univ. of B.C., Vancouver) 1:1-17. 
Lertzman, K.P. 1995. Forest dynamics, differential mortality and variable recruitment probabilities. J. Veg. Sci. 6: 191-204.

Lienard, J., Florescu, I., Strigul, N. 2015. An appraisal of the classic forest succession paradigm with the Shade Tolerance Index. PLoS ONE 10: e01117138.

Lilles, E.B., Astrup, R. Lefrançois, M.L., Coates, K.D. 2014. Sapling leaf trait responses to light, tree height and soil nutrients for three conifer species of contrasting shade tolerance. Tree Physiology 34: 1334-1347.

Lindenmayer D. B. and J. F. Franklin, 2002. Conserving Forest Biodiversity. A Comprehensive Multiscaled Approach. Island Press, Washington, DC.

Lindenmayer D.B., Frankiln J.F., Löumus A. et al. 2012. A major shift to the retention approach for forestry can help resolve some global forest sustainability issues. Conservation Letters 5, 421-431.

Lo Y.-H., Blanco J.A., Kimmins, J.P., Seely B., Welham C. 2011. Linking climate change and forest ecophysiology to project future trends in tree growth: a review of forest models. In Blanco J.A., Kheradmand H. (Eds.) 2011. Climate Change - Research and Technology for adaptation and mitigation. InTech, Rijeka, Croatia. Pp 63-86. ISBN: 979-953-307-278-3.

Lo Y.H., Blanco J.A., Welham C., Wang M. 2015. Maintaining Ecosystem Function by Restoring Forest Biodiversity: Reviewing Decision-Support Tools that link Biology, Hydrology and Geochemistry. In: Lo Y.H., Blanco J.A., Roy S. (Eds.) Biodiversity in Ecosystems: Linking structure and function. InTech. Rijeka. Pp. 143-167. ISBN 978-95351-2028-5.

Lo Y.-H., Lin Y.-C., Blanco J.A., Yu C.-H., Guan B.T. 2012. Moving from ecological conservation to restoration: an example from central Taiwan, Asia. In Blanco J.A., Lo, Y.H. (Eds.) Forest Ecosystems: more than just trees. Pp 339-354. InTech, Rijeka, Croatia. ISBN: 978-953-51-0202-1.

Mailly, D., and J.P. Kimmins. 1997. Growth of Pseudotsuga menziesii and Tsuga heterophylla seedlings along a light gradient: resource allocation and morphological acclimation. Can. J. Bot. 75:1424-1435.

McKenzie, D.A., Tinker, D.B. 2013. A tree-community-level analysis of successional status and gap-phase and postfire regeneration of range-margin Thuja plicata (western redcedar). Can. J. For. Res. 43: 119-128. 
Messier, C. and J.P. Kimmins. 1992. Growth of western redcedar seedlings in relation to microtopography, forest floor nutrient status of fireweed and salal on clearcut sites in coastal British Columbia. Can. J. For. Res. 22: 273-277.

Messier, C., Doucet, R., Ruel, J.C., Claveau, Y., Kelly, C., and Lechowicz, M.J. 1999.

Functional ecology of advance regeneration in relation to light in boreal forests. Can. J. For. Res. 29:812-823

Messier, C., M. J. Fortin, F. Schmiegelow, F. Doyon,S. G. Cumming, J. P. Kimmins, B. Seely, C. Welham and J. Nelson. 2003. Modelling tools to assess the sustainability of forest management scenarios. Chapter 14, pp 531-580, In, P. J. Burton, C. Messier, D. W. Smith and W. L. Adamowicz, (eds). Towards Sustainable Management of the Boreal Forest. NRC Research Press, Ottawa, Ontario.

Nilsson, U., Örlander, G., Karlsson, M. 2006. Establishing mixed forests in Sweden by combining planting and natural regeneration: effects of shelterwoods and scarification. For. Ecol. Manage. 237, 301-311.

Pacala, S.W., Canham, C.D., Silander, J.A., Jr., and Kobe, R.K. 1994. Sapling growth as a function of resources in a north temperate forest. Can. J. For. Res. 24: 2172-2183.

Parent, S. and Messier, C. 1996. A simple and efficient method to estimate microsite light availability under a forest canopy. Can. J. For. Res. 26: 151-154.

Perrera, A. H., L. J. Buse and M. G. Weber. 2004. Emulating Natural Forest Landscape Disturbance. Concepts and Applications. Columbia Univ. Press. 315 pp.

Pojar, J., Klinka, K. and Meidinger, D. 1987. Biogeoclimatic classification in British Columbia. Forest Ecology and Management 22: 119-154.

Prescott, C. and G. Weetman, (Eds.). 1994. Salal Cedar Hemlock Integrated Research Program: A Synthesis. Faculty of Forestry, University of British Columbia. Vancouver, British Columbia.

Prescott, C.E., McDonald, M.A., and Weetman, G.F. 1993. Availability of N and P in the forest floors of adjacent stands of western red cedar - western hemlock and western hemlock amabilis fir on northern Vancouver Island. Can. J. For. Res. 23:605-610.

Puértolas,J., Oliet, J.A., Jacobs, D.F., Benito, L.F., Peñuelas, J.L. 2010. Is light the key factor for success of tube shleters in forest restoration plantings under Mediterranean climates? Forest Ecology and Management 260: 610-617. 
Quinn, G.P., and Keough, M.J., 2002. Experimental design and data analysis for biologist. Cambridge University Press. Cambridge. 556 p.

Sajedi, T., Prescott, C.E., Seely, B., and Lavkulich, L.M. 2012. Relationships among soil moisture, aeration and plant communities in natural and harvested coniferous forests in coastal British Columbia, Canada. J. Ecol. 100(3): 605-608.

Seely, B., J. Nelson, R. Wells, B. Peter, M. Meitner, A. Anderson, H. Harshaw, S.Sheppard, F. Bunnell, H. Kimmins, and D. Harrison. 2004. The application of a hierarchical, decisionsupport system to evaluate multi-objective forest management strategies: A case study in northeastern British Columbia, Canada. . For. Ecol. and Manage. 199 (2004): 283-305

Serrouya, R. and R. D’Eon. 2004. Variable retention forest harvesting: Research synthesis and implementation guidelines. Sustainable Forest Management Network. Univ. of Alberta, Edmonton. 46 pp. www.ualberta.ca/sfm/

Sheppard, S.R.J .and H.W. Harshaw, (eds.). 2000. Forests and Landscapes. Linking Ecology, Sustainability and Aesthetics. CABI Publishing, UK.

Stroh, N., Baltzinger, C., and Martin, J.-L. 2008. Deer prevent western redcedar (Thuja plicata) regeneration in old-growth forests of Haida Gwaii: is there a potential for recovery? For. Ecol. Manage. 256(12): 3973-3979.

Valladares, F. and Niinemets, U., 2008. Shade Tolerance, a Key Plant Feature of Complex Nature and Consequences, Annual Review of Ecology Evolution and Systematics. Annual Review of Ecology Evolution and Systematics, pp. 237-257.

Vázquez de Castro, A., Oliet, J.A., Puértolas, J., Jacobs, D.F. 2014. Light transmissivity of tube shelters affects root growth and biomass allocation of Quercus ilex. L. and Pinus halepensis Mill.

Wang, G.G., Qian, H., and Klinka, K. 1994. Growth of Thuja plicata along a light gradient. Can. J. Bot. 72: 1749-1757.

Weber, A., B. Gilbert, J.P. Kimmins and C.E. Prescott. 2003. Factors limiting the early survivorship of western redcedar (Thuja plicata) on northern Vancouver Island. Can. J. For. Res. 33: 854-861.

Weber, A., J. Karst, B. Gilbert and J. P. Kimmins. 2005. Thuja plicata exclusion in ectomycorrhiza-dominated forests: testing the role of inoculum potential of arbuscular mycorrhizal fungi. Oecolgia, 143: 148-156. 
Weber, A., Kimmins, J.P., Gilbert, B., Lo, Y.H., Blanco, J.A. 2014. Multiple-pathway succession in a coastal Tsuga heterophylla, Thuja plicata, and Abies amabilis forests on northeastern Vancouver Island, British Columbia. Canadian Journal of Forest Research 44: 1145-1155.

Westoby, M., Falster, D.S., Moles, A.T., Vesk, P.A. \& Wright, I.J.(2002) Plant ecological strategies: some leading dimensions of variation between species. Annual Review of Ecology and Systematics, 33: $125-159$.

Wright, E., Coates, KD. and Bartemucci, P. 1998a. Regeneration from seed of six tree species in the interior cedar-hemlock forests of British Columbia as affected by substrate and canopy gap position. Canadian Journal of Forest Research 28: 1352-1364.

Wright, E., Coates, KD., Canham, C. and Bartemucci, P. 1998b. Species variability in growth response to light across climatic regions in northwestern British Columbia. Canadian Journal of Forest Research 28: 871-886. 
Weber et al. (2017)

http://dx.doi.org/10.1016/j.foreco.2016.11.019

Table 1. Initial sizes of redcedar, hemlock and fir seedlings at time of planting. For each

measurement, the mean \pm standard deviation for 20 seedlings are presented. Values followed by different letters indicate significant differences among species with Tukey’s H.S.D. $(\alpha=0.05)$.

\begin{tabular}{lcccc}
\hline \multicolumn{1}{c}{ Tree Species } & Belowground biomass & Aboveground biomass & Height & Root collar diameter \\
& $(\mathbf{g})$ & $(\mathbf{g})$ & $(\mathbf{c m})$ & $(\mathbf{m m})$ \\
\hline Western redcedar & $1.07 \pm 0.34 \mathrm{a}$ & $1.49 \pm 0.45 \mathrm{a}$ & $26 \pm 4 \mathrm{~b}$ & $2.5 \pm 0.3 \mathrm{~b}$ \\
Western hemlock & $0.98 \pm 0.37 \mathrm{a}$ & $1.44 \pm 0.49 \mathrm{a}$ & $30 \pm 4 \mathrm{c}$ & $2.7 \pm 0.3 \mathrm{~b}$ \\
Amabilis fir & $1.62 \pm 0.64 \mathrm{~b}$ & $3.35 \pm 1.14 \mathrm{~b}$ & $15 \pm 4 \mathrm{a}$ & $3.4 \pm 0.6 \mathrm{a}$ \\
\hline
\end{tabular}


Table 2. Comparison of average survival (mean \pm s.d.) for the period 1997-2001 between seedlings grown from seed in the forest and 1-year old planted nursery seedlings (data for regenerated seedlings from Weber et al. 2003).

\begin{tabular}{|c|c|c|c|c|}
\hline \multirow{2}{*}{$\begin{array}{l}\text { Seedling } \\
\text { origin }\end{array}$} & \multirow[t]{2}{*}{ Tree Species } & \multicolumn{3}{|c|}{ Seedling survival } \\
\hline & & Edge $(\%)$ & Interior $(\%)$ & $\begin{array}{c}\text { Change } \\
\text { (\% of edge) }\end{array}$ \\
\hline \multirow[t]{3}{*}{ Planted } & Western redcedar & $98.6 \pm 7.1$ & $94.1 \pm 4.7$ & -4.6 \\
\hline & Western hemlock & $81.5 \pm 8.1$ & $49.3 \pm 37.2$ & -39.5 \\
\hline & Amabilis fir & $93.4 \pm 10.3$ & $23.6 \pm 31.6$ & -74.7 \\
\hline \multirow[t]{3}{*}{ Regenerated } & Western redcedar & 25.5 & 7.7 & -69.8 \\
\hline & Western hemlock & 50.0 & 24.5 & -51.0 \\
\hline & Amabilis fir & 70.0 & 38.4 & -45.1 \\
\hline
\end{tabular}


Table 3. Comparison of height growth $(\mathrm{cm})$ for the period 1998-2001 of 1-year old planted nursery seedlings and for 1997-2000 for seedlings grown in the forest from seed (data for regenerated seedlings from Weber et al. 2003).

\begin{tabular}{|c|c|c|c|c|}
\hline \multirow[t]{2}{*}{ Seedling origin } & \multirow[t]{2}{*}{ Tree species } & \multicolumn{3}{|c|}{ Height growth } \\
\hline & & $\begin{array}{l}\text { Edge } \\
(\mathrm{cm})\end{array}$ & $\begin{array}{c}\text { Interior } \\
\text { (cm) }\end{array}$ & $\begin{array}{c}\text { Change } \\
(\% \text { of edge) }\end{array}$ \\
\hline \multirow[t]{3}{*}{ Planted } & Western redcedar & $8.5 \pm 4.9$ & $9.7 \pm 4.1$ & +14.1 \\
\hline & Western hemlock & $30.5 \pm 14.7$ & $9.4 \pm 4.4$ & -69.2 \\
\hline & Amabilis fir & $14.0 \pm 3.7$ & $0.7 \pm 1.7$ & -95.0 \\
\hline \multirow[t]{3}{*}{ Regenerated } & Western redcedar & 23 & 24 & +4.3 \\
\hline & Western hemlock & 35 & 20 & -42.9 \\
\hline & Amabilis fir & 37 & 38 & +2.7 \\
\hline
\end{tabular}


Weber et al. (2017)

http://dx.doi.org/10.1016/j.foreco.2016.11.019

Table 4. Change in height/diameter (H/D) ratios (in $\mathrm{mm}$ ) for the 1998-2001 period for seedlings planted in two different plot types compared with values for the original 1-year old seedlings that were planted, and compared to data from Karakatsoulis (2004). na: non-applicable.

\begin{tabular}{lcccccccc}
\hline \multicolumn{1}{c}{ Tree species } & \multicolumn{3}{c}{ Data from this work } & \multicolumn{3}{c}{ Data from Karakatsoulis (2004) } \\
& & & \multicolumn{3}{c}{ Change } & & Change $(\%$ \\
& Original & Edge & Interior & $(\%$ edge $)$ & $\mathbf{4 5 \%}$ Light & $\mathbf{3 \%}$ Light & $\mathbf{4 5 \%}$ light) \\
\hline Western redcedar & 104.0 & 111.8 & 173.2 & +54.9 & 93 & 106 & +14.0 \\
Western hemlock & 111.1 & 57.7 & 110.6 & +91.7 & 69 & 82 & +18.8 \\
Amabilis fir & 44.1 & 36.5 & 12.5 & -65.8 & na & na & na \\
Douglas-fir & na & na & na & na & 50 & 91 & +82.0 \\
\hline
\end{tabular}


Weber et al. (2017)

Table 5. Shade tolerance rankings of the three studied species based on different survival and growth variables. Overall ranking is calculated by adding up the scores given by the rankings of the four individual parameters (sum in brackets).

\begin{tabular}{lccc}
\hline Parameter & Western redcedar & Western hemlock & Amabilis fir \\
\hline Survival of regenerated seedlings & $3^{\text {rd }}$ & $2^{\text {nd }}$ & $1^{\text {st }}$ \\
Survival of planted seedlings & $1^{\text {st }}$ & $2^{\text {nd }}$ & $3^{\text {rd }}$ \\
Biomass growth & $1^{\text {st }}$ & $3^{\text {rd }}$ & $2^{\text {nd }}$ \\
Height growth & $3^{\text {rd }}$ & $2^{\text {nd }}$ & $1^{\text {st }}$ \\
Diameter growth & $1^{\text {st }}$ & $3^{\text {rd }}$ & $2^{\text {nd }}$ \\
Observed natural regeneration & $3^{\text {rd }}$ & $2^{\text {nd }}$ & $1^{\text {st }}$ \\
Height : diameter ratio & $2^{\text {nd }}$ & $3^{\text {rd }}$ & $1^{\text {st }}$ \\
Overall ranking & $\mathbf{2}^{\text {nd }}(\mathbf{1 4})$ & $\mathbf{3}^{\text {rd }}(\mathbf{1 7})$ & $\mathbf{1}^{\text {st }}(\mathbf{1 1})$
\end{tabular}

${ }^{\mathrm{a}}$ Data from Weber et al. (2003). 


\section{Figures}

Figure 1. Proportion of amabilis fir, western redcedar, and western hemlock that survived the first growing season after planting (period 1997-1998, top panel) and survival for the period 1998-2001 (bottom panel).

Figure 2. Proportion of western redcedar seedlings alive at the end of the first growing season (1998) that survived to the end of the study (2001) when treated to different combinations of fertilization and browsing protection (Vexar@ collars).

Figure 3. Height growth (top panel), root collar diameter growth (central panel), and aboveground mass increment (bottom panel) of amabilis fir, western redcedar and western hemlock in interior and edge plots for the period 1998-2001.

Figure 4. Height growth (top panel), root collar diameter growth (central panel), and aboveground mass increase (bottom panel) of western redcedar seedlings in interior and edge plots under different treatments of fertilization and browsing protection (Vexar@ collars) for the period 1998-2001. 
Survival first growing season (1997-1998)

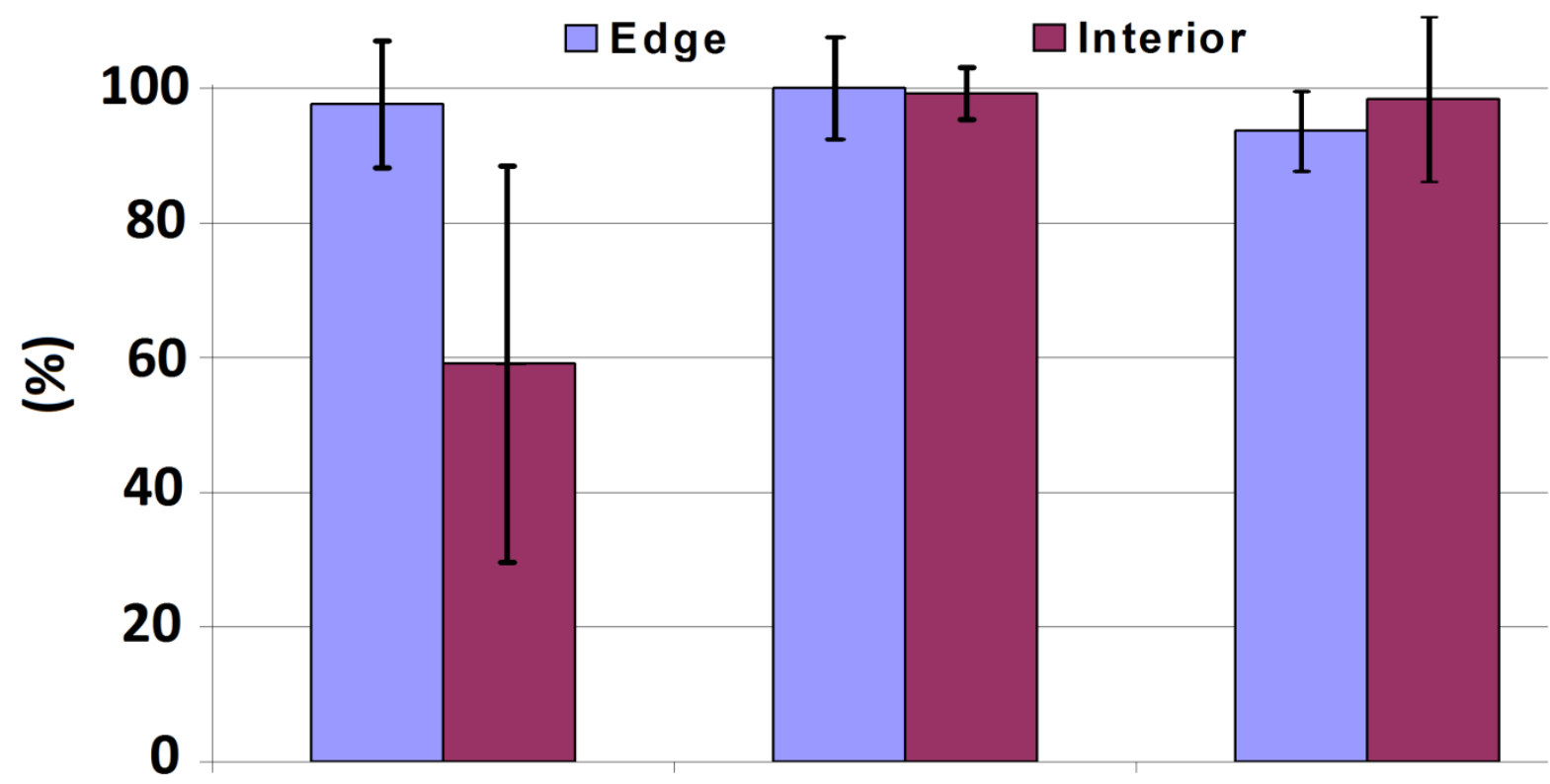

Survival from 1998 to 2001

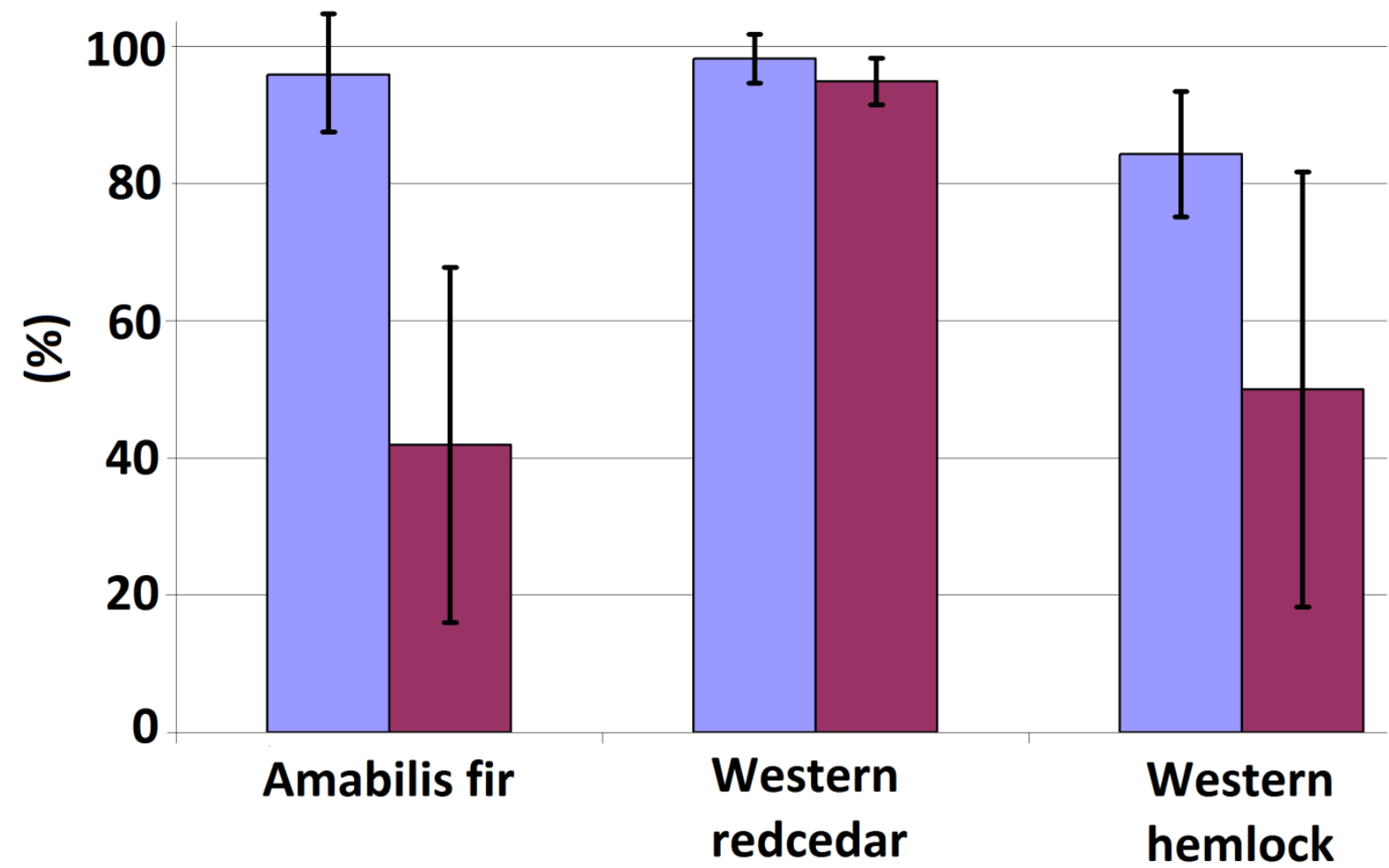

Figure 1 


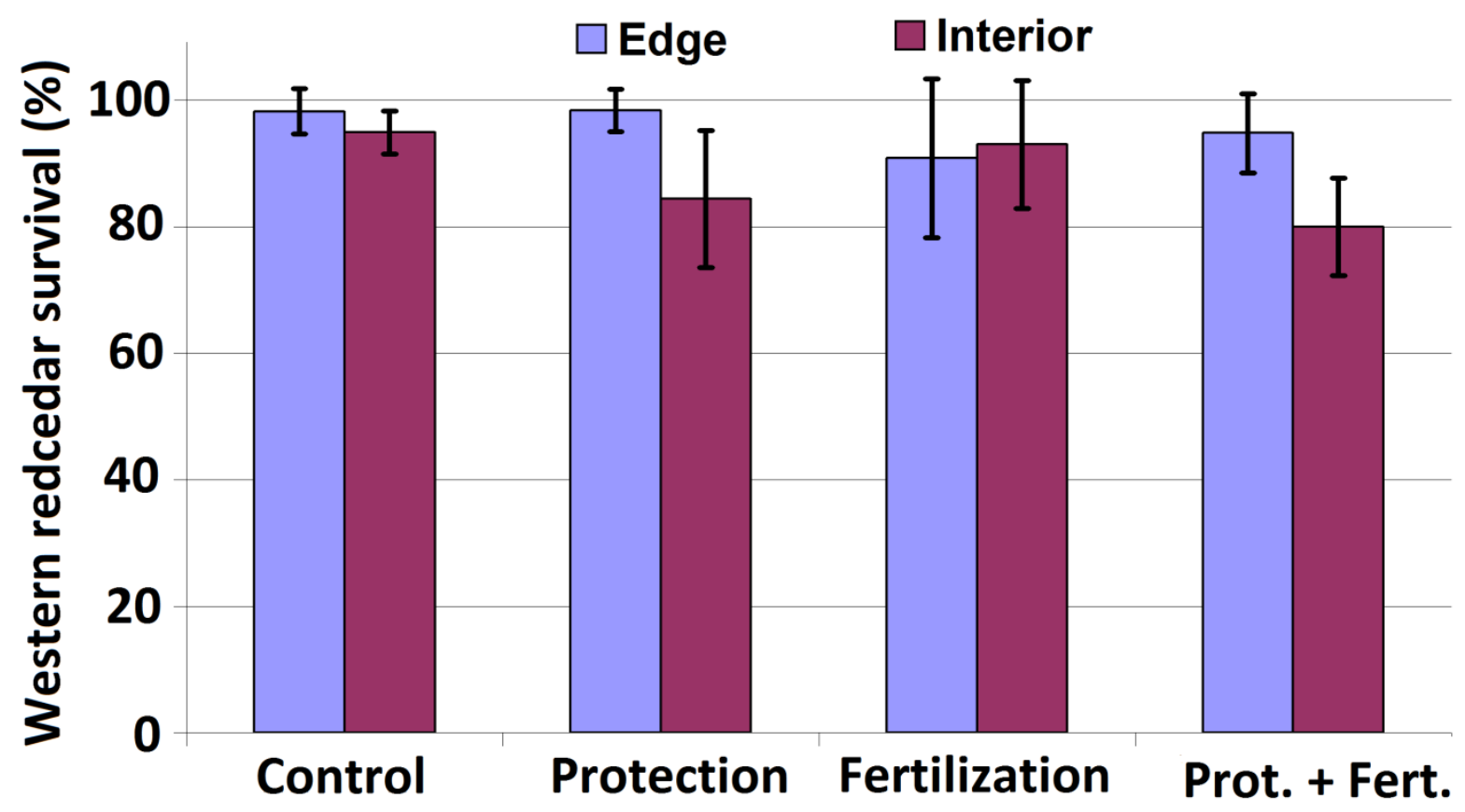

Figure 2 

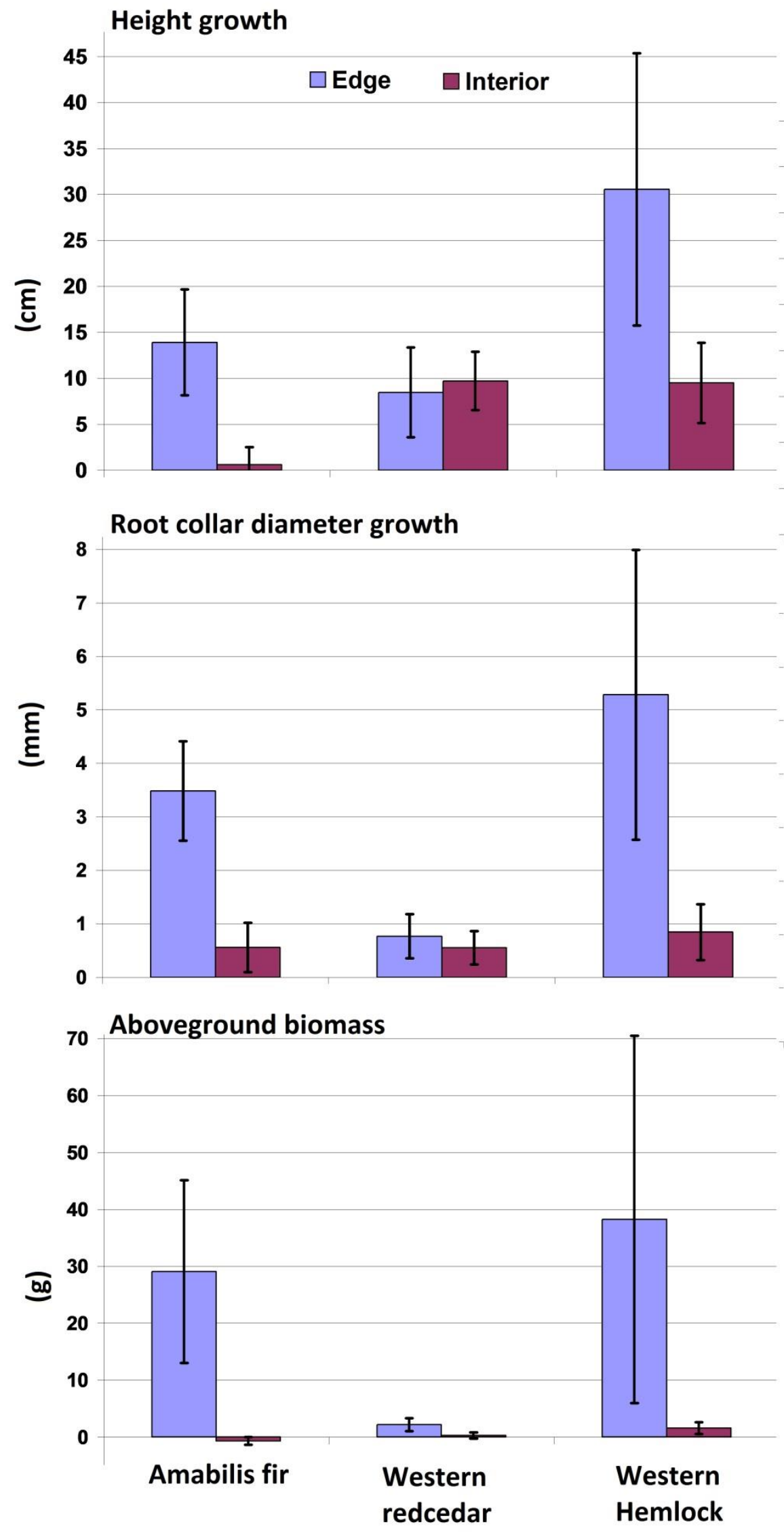

Figure 3 

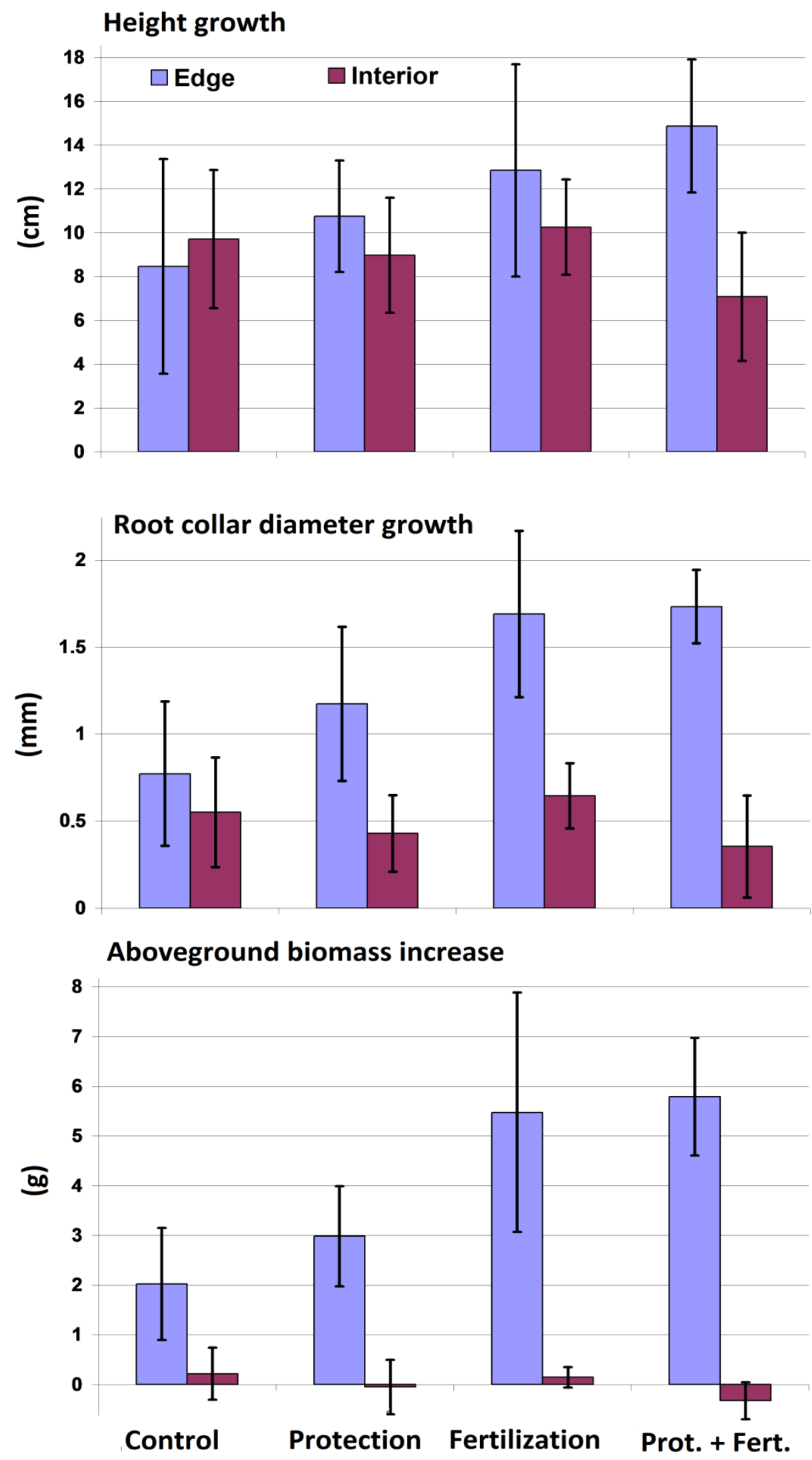

Figure 4 